\title{
Enlightened Understanding, Empowerment and Leadership - Three Ways to Enhance Multiculturalism: Comment on Will Kymlicka's article: "Solidarity in Diverse Societies"
}

\author{
Hanspeter Kriesi
}

Correspondence: Hanspeter.Kriesi@ eui.eu

Stein Rokkan Chair, EUI (European University Institute), Florence, Italy

\section{㳕 Springer}

In my comment on Will Kymlicka's (2015), very stimulating essay, I would like to argue that his basic scheme is sound, but incomplete and that his proposal for the progressive forces falls short in several respects. To begin with, Will Kymlicka stresses, in my view correctly, that the welfare state is built on national solidarity. The idea of the 'people's home' (folkshemmet) of the Swedish Social Democrats, to which he refers in his text, serves as a perfect illustration of this point. Even the 'universalistic' Nordic welfare state intends to be universalistic within the boundaries of the national political community only. The welfare state is, as Kymlicka underlines, generally tied to an image of social membership, not to universal humanitarianism. In this respect it is important to keep in mind, as Kymlicka also argues, that the national community is conceived in egalitarian terms: the two fundamental principles of the nation - popular sovereignty and equality of all members of the national community - are at the same time the two core principles of democracy (Greenfeld, 1992: 10). The idea of democracy was, in Greenfeld's nice formulation, contained in the idea of the nation like the butterfly in the chrysalis. (Kymlicka, 2015).

Accordingly, Kymlicka (2015), suggests that appeals to national solidarity constitute a resource for progressives. One might add that appeals to national solidarity fall on particularly open ears among the poor, who identify more with the nation than the rich, because they have less to be proud of in their immediate social group compared to the rich and because they are more similar to the average member of their nation (Shayo, 2009: 162). However, national solidarity is an ambiguous resource for progressives - not only, as Kymlicka argues, because of its tendency to exclude groups not perceived as belonging to the nation, but also for yet another reason: as Shayo (2009) shows, people with a strong national identity are less supportive of redistribution in general, and, at the macro-level, the most nationalistic countries are known for being those with the least redistributive welfare states (and vice versa). The Swedes may again serve as an illustrative example. They are comparatively (compared to the Anglo-Saxon settler states, in particular) little nationalistic - class identities were relatively strong compared to national identities in Sweden - and, accordingly, Sweden did

(c) 2016 Kriesi. Open Access This article is distributed under the terms of the Creative Commons Attribution 4.0 International License (http://creativecommons.org/licenses/by/4.0/), which permits unrestricted use, distribution, and reproduction in any medium, provided you give appropriate credit to the original author(s) and the source, provide a link to the Creative Commons license, and indicate if changes were made. 
construct a relatively redistributive welfare state. If the construction of the 'folkshemmet' did benefit from appeals to national solidarity, we should not forget that it was above all constructed by a social movement based on class identities, a movement that, in the process, succeeded in decisively shaping the Swedish national identity - constructing a 'social democratic image of society', as Frank Castles (1978) has aptly put it.

However, as Kymlicka (2015), goes on in his argument, national solidarity is not only a resource for progressives, but it also poses endemic risks for all those who are not perceived as belonging to the nation. His list of excluded groups (indigenous peoples, sub-state national groups and immigrants) is, however, incomplete. First of all, national solidarity generally tends to exclude those members of the nation who are perceived as undeserving - because they are perceived as not having appropriately contributed to the common good (in violation of the norm of reciprocity), or because they are perceived as abusing the common good (in violation of the norm of self-reliance). Second, with respect to the non-nationals, we need to distinguish between immigrants on the national territory and the residents of other nation-states. Thus, within the European Union, not only the immigrants pose problems for national solidarity, but also the claims of other member-states, as has been illustrated by the recent Euro-crisis and the European refugees' crisis: the Germans are called upon to be solidary not only with the flood of refugees, but also with the Greeks. Third, with respect to immigrants in particular, we should distinguish between access to the national territory and integration of those who have gotten access and are likely here to stay. To counter the endemic risks of national solidarity, Kymlicka argues that we need multiculturalism. However, if multiculturalism may contribute to counter the exclusion of the second and third type, it may not at all help to counteract the exclusion of the first type. Moreover, the measures of multiculturalism it takes to enhance solidarity with other nations, or to grant access to immigrants in the first place, may well be different from the measures designed to integrate immigrants who are already more or less permanent residents in one's country.

The progressives' dilemma, as Kymlicka (2015), sees it, derives from the fact that, while we need multiculturalism to counteract the endemic risks of national solidarity, it at the same time undermines national solidarity. For Kymlicka, this dilemma is expressed by the stark contrast between neoliberal multiculturalism (inclusion without solidarity) and welfare chauvinism (solidarity without inclusion). On the one hand, multiculturalism may degenerate into a project of market inclusion rather than citizenship. On the other hand, national solidarity may degenerate into welfare chauvinism - an attitude that supports a 'system of social protection only for those who belong to the ethnically defined community and who have contributed to it' (Kitschelt \& McGann, 1995), and, I would add, into welfare populism an attitude that combines a sense of egalitarianism with the exclusion of the undeserving poor (De Koster, Achterberg \& Van der Waal, 2012, Michel, 2015). The way out proposed by Kymlicka constitutes a third option - solidarity with inclusion. This way to frame the alternatives, however, leaves out a fourth option, which has actually been the one originally embraced by the European radical populist right and which, according to Kitschelt and McGann (1995), represented its 'winning formula': nationalist neoliberalism, i.e., in Kymlicka's terms, exclusion without solidarity. Figure 1 situates the four options. 


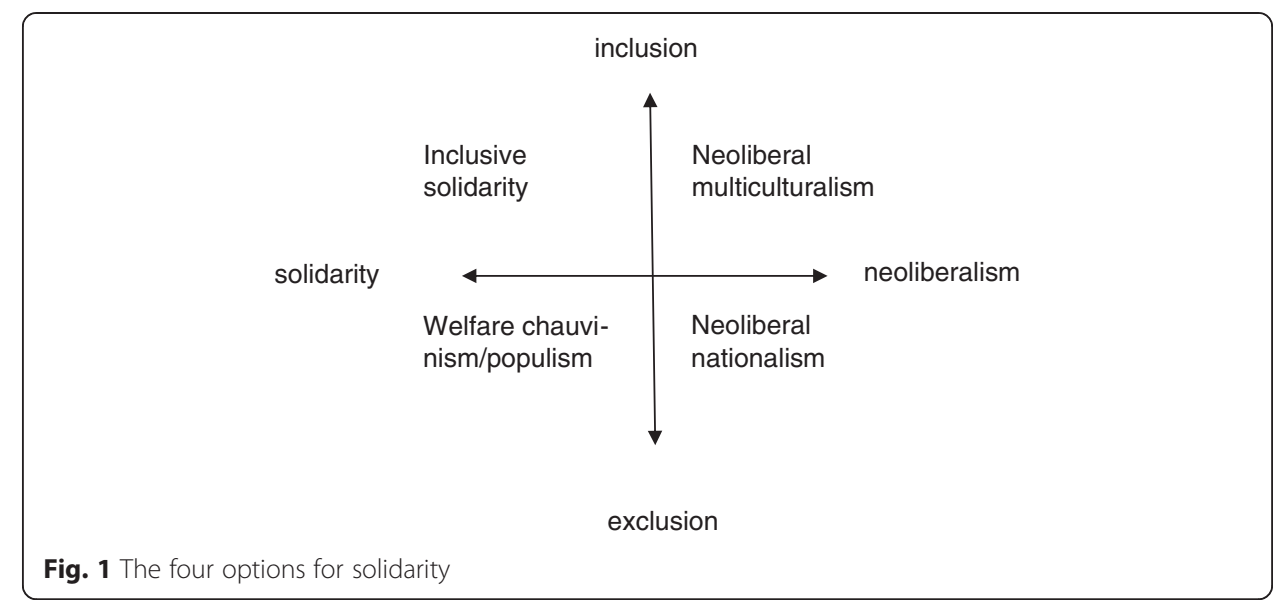

Now, it seems to me that, at least in Western Europe, the progressives (i.e., the left) have always embraced the option of inclusive solidarity: they have always been solidary (in the sense of attributing priority to the norm of equality over the norms of reciprocity and self-reliance), and multicultural (in the sense of favoring international solidarity and inclusiveness of the national solidarity). The problem for the progressives is that their traditional constituency has not followed suit, but has been attracted by the appeals of the new populist right, which, in response to its success in the working class, has gradually been shifting its position from its original nationalist neoliberalism towards welfare chauvinism and welfare populism. As a result of these corresponding shifts on the demand and the supply side of the political space, the progressives' constituency has become predominantly middle class. More specifically, it has become dominated by the social and cultural professionals who form a key segment of the new middle class and for whom the inclusive solidarity of the progressives has been most appealing. Formulated in somewhat different terms, the dilemma of the progressives (the left) is that they need to forge an alliance between their traditional and their new constituencies both of whom agree in terms of national solidarity, but who could not be more different in terms of inclusion. Or, more pointedly, the core of the dilemma of the progressives is that their traditional constituency does not endorse multiculturalism.

How to attenuate the opposition of the working class to multiculturalism? This is the million dollar question. At this point, arguments about the relative weight of cultural and economic threats typically enter the discussion, but, increasingly, I tend to think that, in reality, the distinction between the two types of threat is difficult to make, because the borderline between the two is blurred (Häusermann \& Kriesi, 2015): increasing economic security is likely to attenuate the perception of cultural threats, just as increasing cultural confidence is likely to attenuate the perception of economic insecurity. I would like to suggest that the two kinds of threats have common roots - ignorance, powerlessness, and disorientation - and require common countervailing measures - 'enlightened understanding', as Dahl $(1989,1998)$ used to put it, empowerment and leadership. The emphasis on specific types of countervailing measures is likely to vary, however, from one form of exclusion to the other. With respect to the exclusion of those members of the national community who are perceived as 
undeserving, multiculturalism may be above all strengthened by a continuous flow of information in the media about the (typically structurally determined) needs of the allegedly undeserving beneficiaries, about the (often rather limited) number of cases involved, and about the prevailing (often quite judicious) administrative measures to deal with these issues. This kind of factual information should help to dispel the beliefs about violations of the norms of self-reliance and reciprocity. Of course, expecting this kind of information to have the desired impact is a tall order, because such information has to compete with the media's penchant for reporting on individual cases of abuse and with the individuals' penchant for motivated reasoning, i.e., for receiving and accepting only information that is in line with their biased preconceptions. With respect to solidarity with other nations within the European Union, it is above all democratic empowerment that might help: to the extent that the democratic deficit of the EU is alleviated, i.e., to the extent that European citizens are empowered to jointly decide about their fate at the European level, they can be expected to develop a common European identity and become a solidary European demos. This at least was the argument of Habermas' $(1995,1998)$ 'constitutional patriotism': the democratic practice as the precondition for the development of a common identity, which is in turn the precondition for solidarity. The Swiss case may serve to illustrate the pertinence of Habermas' argument (see Lacey, 2015). With respect to the access of immigrants, Ms. Merkel singlehandedly demonstrated during the summer 2015 to what extent political leadership can make a difference. We might want to add that leadership does not end with bold declarations, but ought to be followed up by administrative measures that credibly implement these declarations. Finally, as far as the integration of immigrants who have already gotten access to the country in question is concerned, enabling the immigrants to express their culture and identity as modes of participating and contributing to the national society, as proposed by Kymlicka (2015), in my view, indeed, constitutes a form of empowerment that promises to contribute to their integration into the host society.

Received: 3 December 2015 Accepted: 3 December 2015

Published online: 17 December 2015

References

Castles, F. G. (1978). The Social Democratic Image of Society. London: Routledge.

Dahl, R. A. (1989). Democracy and its Critics. New Haven: Yale University Press.

Dahl, R. A. (1998). On democracy. New Haven: Yale University Press.

De Koster, W. Achterberg, P. \& Van der Waal, J. (2012). The new right and the welfare state: The electoral relevance of welfare chauvinism and welfare populism in the Netherlands. International Political Science Review, 34(1):3-20. Greenfeld, L. (1992). Nationalism: Five Roads to Modernity. Cambridge: Harvard University Press.

Habermas, J. (1995). The European Nation-state - its achievements and its limits. On the past and future of sovereignty and citizenship'. In G. Balakrishnan \& B. Anderson (Eds.), Mapping the Nation (pp. 281-294). London: Verso.

Habermas, J. (1998). Die postnationale Konstellation. Frankfurt: Suhrkamp.

Häusermann, S. \& Kriesi, H. (2015). What Do Voters Want? Dimensions and Configurations in Individual-Level Preferences and Party Choice. In P. Beramendi et al. (Eds.), The Politics of Advanced Capitalism (pp. 202-230). Cambridge: University Press.

Kitschelt, H. \& McGann, A. J. (1995). The Radical Right in Western Europe: A Comparative Anaylsis. Ann Arbor: University of Michigan Press.

Kymlicka, W. (2015). Solidarity in Diverse Societies: Beyond Neoliberal Multiculturalism and Welfare Chauvinism. Paper presented at the IMISCOE "Mobility in Crisis" conference at the European University Institute, Florence, Italy.

Lacey, J. (2015). Centripetal democracy. Democratic legitimacy in Belgium, Switzerland and the European Union. (Unpublished doctoral dissertation). European University Institute.

Michel, E. (2015). The radical right and the welfare state: the electoral relevance of welfare politics. (Unpublished doctoral dissertation). European University Institute.

Shayo, M. (2009). A Model of Social Identity with an Application to Political Economy: Nation, Class, and Redistribution. American Political Science Review, 103(2):147-17. 